\title{
Practical Skills of Pakistani and Indonesian Students A Comparative Analysis
}

\author{
Naseer Ahmed ${ }^{1, *}$ Tri Joko Raharjo ${ }^{1,}$ Khandil Badshah $^{2,}$ Sajad $^{1}$ \\ ${ }^{1}$ Faculty of Mathematics and Natural Sciences, Universitas Gajah Mada, Indonesia \\ ${ }^{2}$ Department of Chemistry, Government Postgraduate College Haripur, Pakistan \\ ${ }^{*}$ Corresponding author. Email: naseerahmed1992@gmail.com
}

\begin{abstract}
In the science learning process practical always have a significant role especially chemistry learning is completed with practical. Chemistry student's concepts clear after the practical performance in the laboratory. The purpose of this research is to improve the learning process in chemistry by comparing two countries' students' practical skills, especially experimental and manipulative, observation, drawing and reporting, and interpretive skills. This research is an experimental, observation sheet used for data collection, observation sheet was validated by three experts, reliability was checked in one class in both countries and modified for data collection. 71 Pakistani and 70 Indonesian organic chemistry undergraduate students were under observation, independent t-test used for data analysis. According to results, there is a significant difference between Pakistani and Indonesian students' practical skills in general, while according to each aspect Indonesian student's practical skills dominate Pakistani students in experimental and manipulative skills. On the other hand, in observation skills, drawing skills, and reporting and interpretive skills, there was no significant difference found, hence Indonesian and Pakistani students have the same practical skills in the last three aspect. Research can be held with different aspects for different results.
\end{abstract}

Keywords: Aspects of practical skills, Chemistry learning, Indonesian undergraduate students, Pakistani undergraduate students' practical skills

\section{INTRODUCTION}

The teaching and learning in laboratory work and laboratory skills have been part of science subjects and especially chemistry is the branch of sciences that is incomplete without a practical course [14]. However, the practical lessons can be traced back to the 19th century [7]. Teaching in the laboratory has been considering for a long time for its role in enhancing positive student attitudes about science and developing students' interest in the ability to the usage of equipment [11]. Laboratory work is one of the main forms of teaching used in all undergraduate chemistry courses, and most chemistry educators agree that laboratory work has fundamental role in Practical work in science subjects is necessary and essential to creating a learning environment and situation that urges students to develop an interest and attention in experimentally-based practical skills [1]. In laboratory work, the first step is thinking about planning practical then feeling and at the end doing practical work, and the science laboratory is a hub of interactions the lab work stage needed better teaching assistants' performance [21]. The learning environment is affected by student-teacher relationships and this relation is an important problem in the inquiry-based laboratory [13].

Inquiry and problem-based laboratory learning can increase the students' ability in thinking skills and practical skills [6]. Planning and carrying out experiments and investigations, the science outcome is a distinctly separate form that can be tested by his, her, their, etc. conventional pen and paper tests [8]. Students define the well-planned laboratory practices as motivating and effective, most of them also prefer laboratory practices rather than theoretical courses [(9]. Laboratory work in universities was needed to train three areas that that were practical skills, transferable skills, and intellectual stimulation [20].

Practical skills can be obtained by giving full opportunities to students to design their experiments in the chemistry laboratory lab which pursue students and help in the learning process [10]. Practical in chemistry for undergraduates is necessary as this is the level where the chemistry students can improve their 
practical skills to be more efficient in understanding basic concepts practically and ready for their work as analytical, biochemist, and organic chemists or as researchers in postgraduate studies [23]. The practical skills approach can be used to solve the problem of improving and solving the quality of organic chemistry [7]. The post-lab stage could be in the form of a simple assessment of what had happened during the experiment stage in the laboratory [4]. Laboratory practices conducted in the traditional method, result in shortcomings and deficiencies in the practices [12]. The right use of chemicals which are mostly required in a small quantity, in each experiment where sometimes melting point measurement is necessary the students can measure the melting in an organic laboratory of undergraduate students, a water source is always important as a continuous supply is necessary because in synthesis, distillation, and refluxing processes [19].

Pakistan's curriculum has three broad categories of activities that define the critical abilities of scientifically literate students in Pakistan. These are knowing and using science knowledge (learning science), constructing new science knowledge (doing science), and reflecting on science knowledge (thinking science). These broad performance indicators are linked to standards and benchmarks that describe what knowledge and skills students should acquire in the subject [3]. A study in Pakistan found visible gaps in between-curricular demands and cognitive levels of middle-grade students. [15]. Standard chemistry, learning materials for bilingual teaching is very important to be used in the teaching and learning activities in Indonesia. It could help the students to understand the chemistry concept clearly, and make the learner free from students' misconceptions on specific chemistry terms. Many SHS (Senior high school) students see chemistry as a difficult subject, which makes them not interested in learning [5]. The main purpose of this study is to improve the learning process by comparing practical skills in chemistry between two countries after it can know about what teaching method has to adopt that can increase learning skills and also practical skills.

\section{RESEARCH METHOD}

The method of this research was experimental. The main purpose of this research was to know about the comparison between Pakistani and Indonesian chemistry students' practical skills regarding different aspects and in general as well. This research was held in one of the universities in the Special Region of Yogyakarta Indonesia and in one of the Government Postgraduate colleges in Haripur Pakistan. There were four classes population in Pakistan while three classes in Indonesia, out of which 70 samples from Indonesia while 71 from Pakistan took, the samples consist of 70 undergraduate chemistry students from Indonesia and 71 from Pakistan. The observers were informed about the confidentiality for filling of observation sheets about practical skills. This research was completed in five meetings, students were observers by observers. On each table there were two observers and there were three tables in laboratories in each country. An observation sheet was used as an observing instrument which contains 15 items to observe students' practical skills, that covers experimental and manipulative, observations skills, drawing skills, writing and interpretive skills. It was in English language example of samples given below in tables 1 and 2 which explains the criteria of observations. Instruments were validated by three experts and experts mentioned mistakes that were mostly grammatically and need change were corrected as per requirement. After validations quality of instruments checked in on of class whether these instruments cover all aspects in experiments or needed to improve and addition in order to qualify for reliability. Mistakes were corrected and added some more items in observation sheet and then data collected. Scores category were on "very good", "good", "sufficient" and "poor" basis. Data were analyzed by using an independent sample t-test, in order to compare Pakistani and Indonesian students' practical skills.

Table 1. Sample of observation sheet

While statements that used in observation sheet given in table 2.

\begin{tabular}{|l|c|l|l|l|l|l|l|l|l|l|l|l|l|l|l|l|l|}
\hline No. & $\begin{array}{c}\text { Name of } \\
\text { Undergraduate } \\
\text { Students }\end{array}$ & 1 & 2 & 3 & 4 & 5 & 6 & 7 & 8 & 9 & 10 & 11 & 12 & 13 & 14 & 15 & Mode \\
\hline 1 & & & & & & & & & & & & & & & & & \\
\hline 2 & & & & & & & & & & & & & & & & & \\
\hline 3 & & & & & & & & & & & & & & & & & \\
\hline
\end{tabular}


Table 2. Statements of observation sheet

\begin{tabular}{|l|l|}
\hline No. & Statements \\
\hline 1 & Undergraduate student using apparatus appropriately. \\
\hline 2 & Undergraduate students' weighing chemicals accurately. \\
\hline 3 & Organic chemistry undergraduate students choosing reactants in an appropriate amount. \\
\hline
\end{tabular}

\section{RESULT AND DISCUSSION}

Results obtained from the comparison between two countries students Indonesia and Pakistan is a sign of both countries students have different practical skills level however in some aspects both countries students have the same level of practical skills in a chemistry lab.

\subsection{Results on The Base of The Mean Score}

There is $\mathrm{N}$ which indicates the number of students whose practical skills were observed by observers, Pakistani students were $(\mathrm{N}=71)$ while Indonesian students $(\mathrm{N}=70)$. As result, Pakistani student's means score is 49.8451 while Indonesian student's mean score about practical skills is 61.5571 which is a clear sign that Indonesian students have high skills in chemistry practical's compared to Pakistan. While the Standard deviation value for Pakistani students' practical skills is 2.90147 and for Indonesian student's practical's skills is 3.46676 , it proves that there is also a big standard deviation difference between Pakistani students' practical skills and Indonesian students' practical skills. The standard error mean for Pakistani

Table 4. Levene's test for equality of variance

\begin{tabular}{|l|l|l|l|l|l|}
\hline \multirow{2}{*}{} & \multicolumn{2}{|l|}{$\begin{array}{l}\text { Levene's Test for Equality of } \\
\text { Variances }\end{array}$} & \multicolumn{2}{l|}{$\begin{array}{l}\text { T-test for Equality of } \\
\text { Means }\end{array}$} & Conclusion \\
\hline \multirow{2}{*}{$\begin{array}{l}\text { Equal variances } \\
\text { assume }\end{array}$} & $\mathrm{F}$ & Sig. & $\mathrm{T}$ & Sig (2-tailed) & \\
\cline { 2 - 6 } & 2.35 & 0.12 & -21.76 & 0.000 & $\begin{array}{l}\text { There is significant } \\
\text { difference }\end{array}$ \\
$\begin{array}{c}\text { Equal variances not } \\
\text { assume }\end{array}$ & & -21.73 & 0.000 & \\
\hline
\end{tabular}

While t-test for equality of means shows $\mathrm{P}<0.05$ which is sig $=0.00$ and it's less than P-value $0.00<0.05$ hence $\mathrm{H} 0$ hypothesis rejected and shows that there is a significant difference between Pakistani students and Indonesian students' practical skills in a chemistry lab. $\mathrm{T}$ values are -21. 766 overall practical skills of Pakistani and Indonesian students in chemistry practical are significantly different as mentioned in the above table also that mean score of Indonesian students' practical skills is higher than Pakistani chemistry students. students is 0.34434 while for Indonesian students 0.41436 . Details are given in the table 3 .

Table 3. Mean score of both countries' students

\begin{tabular}{|l|l|l|}
\hline \multicolumn{3}{|l|}{ Practical skills } \\
\hline $\begin{array}{l}\text { Students } \\
\text { Comparison }\end{array}$ & $\begin{array}{l}\text { Pakistani } \\
\text { Students }\end{array}$ & $\begin{array}{l}\text { Indonesian } \\
\text { Students }\end{array}$ \\
\hline N & 71 & 70 \\
\hline Mean & 498.451 & 615.571 \\
\hline Std. Deviation & 290.147 & 346.676 \\
\hline Std. Error" Mean & 0.34434 & 0.41436 \\
\hline
\end{tabular}

\subsection{Result on The Base of Levene's Test for Equality Variance}

Levene's test is divided into two parts first part explains the homogeneity between two variables, here $\mathrm{P}>0.05$ which is $0.127>0.05$, so the H0 hypothesis accepted and data is normally distributed and variability in both variables same, hence equal variances assumed. $\mathrm{F}=2.354$ shows about the null hypothesis as its value is $2.354>0.05$ its means that data is normally distributed and homogeneous. As in the table 4.

\subsection{Results on the base of each aspect of practical skills}

Results on the base of each aspect of practical skills Practical aspects have a lot of aspects in this research only four practical skills aspects were taken which include, experimental and manipulative skills in which students' activities during practical observe by observers. The way of using instruments and chemical usage and all other activities observed here. The 
second skill is observational skill how students were observing chemical changes during practical's whether they were accurate or no at the endpoint and using chemicals on each step. The third is drawing skills which include how students draw their practical work in graphs, tables, and suitable diagrams if needed. The fourth skill is about reporting of practical work and interpretation of their practical work where students reporting skills and their interpretation skills check. Results show that in experimental and manipulative skills $(\mathrm{N}=71)$ Pakistani students participated while $(\mathrm{N}=70)$ Indonesian students participated, the mean score for Pakistani students is 14.6479 while for Indonesian students 25.6429 which shows that Indonesian students show the high score in experimental and manipulative skills. The standard deviation for Pakistani students is 2.31207 while for Indonesian students 3.02183 and here is also quite a difference between the two countries students, standard error mean for Pakistani students .27439 and for Indonesian students is .36118.

In observation skills $(\mathrm{N}=71)$ Pakistani students participated and Indonesian students were $(\mathrm{N}=70)$ mean score showed by Pakistani students is 14.0423 and by Indonesian students 14.4286 in observational skills, the mean score shows that both Pakistani and Indonesian students almost have a same mean score. The standard deviation for Pakistani students 1.90065 while for Indonesian students 1.08443 and the standard error mean 0.22557 and .12961 for both Pakistani and Indonesian students respectively. All these results show that in observational skills both Pakistani and Indonesian students have the same skills. In drawing skills total $(\mathrm{N}=71)$ Pakistani students and $(\mathrm{N}=70)$ Indonesian students participated.

The mean score for Pakistani students is 11.0141 and for Indonesian students is 11.2000 which shows that both Pakistani and Indonesian students have the same drawing skills. The standard deviation for Pakistani students 1.44907 for Indonesian students is 1.00145 while the standard error means for Pakistani and Indonesian students is 0.17197 and 0.11970 respectively these results also show Pakistani and Indonesian students both have almost the same drawing skills. In reporting and interpreting skills $(\mathrm{N}=71)$ and $(\mathrm{N}=71)$ Pakistani and Indonesian students respectively participated. Mean score for Pakistani students is 14.0423 while for Indonesian students is 14.4286 both means score shows similarities in reporting and interpreting skills of Pakistani and Indonesian students. Standard deviation is 1.90065 and 1.08443 while standard error means .22557 and .12961 for Pakistani and Indonesian students respectively which shows that all participated students show equal reporting and interpretive skill.

Table 5. Mean score of practical skills aspects

\begin{tabular}{|l|l|l|l|l|l|}
\hline \multirow{2}{*}{ Practical skills } & $\begin{array}{l}\text { Student's } \\
\text { Comparison }\end{array}$ & N & Mean & Std. Deviation & $\begin{array}{l}\text { Std. Error } \\
\text { Mean }\end{array}$ \\
\hline \multirow{2}{*}{$\begin{array}{l}\text { Experimental and } \\
\text { Manipulative skills }\end{array}$} & Pakistani & 71 & 146.479 & 231.207 & 0.27439 \\
\cline { 2 - 6 } & Indonesian & 70 & 256.429 & 302.183 & 0.36118 \\
\hline \multirow{2}{*}{ Observational skills } & Pakistani & 71 & 140.423 & 190.065 & 0.22557 \\
\cline { 2 - 6 } & Indonesian & 70 & 144.286 & 108.443 & 0.12961 \\
\hline \multirow{2}{*}{ Drawing skills } & Pakistani & 71 & 110.141 & 144.907 & 0.17197 \\
\cline { 2 - 6 } & Indonesian & 70 & 112.000 & 100.145 & 0.11970 \\
\hline \multirow{2}{*}{$\begin{array}{l}\text { Reporting and } \\
\text { Interpretive skills }\end{array}$} & Pakistani & 71 & 140.423 & 190.065 & 0.22557 \\
\cline { 2 - 6 } & Indonesian & 70 & 144.286 & 108.443 & 0.12961 \\
\hline
\end{tabular}

\subsection{Results on The Base of Each Aspect According to Levene's}

Levene's test gives an explanation about whether variables used in research are equally assumed or not, and the second part shows data there is a significant difference or no. In this research four aspects of practical skills used to observe students' skills of Pakistani and Indonesian students.in experimental and manipulative skills P-value is less than 0.05 which is $0.02<0.05$ hence equal variance not assumed in t-test for equality P-value is less than 0.05 which shows that there is a significant difference between Pakistani students and Indonesian students experimental and manipulative skills value is $0.00<0.05$. For observational skills, Levene's test for equality of variance shows that sig value is 0.00 which is less than 0.05 hence equality of variance not 
assumed. In the t-test for equality sig value is 0.140 which is bigger than 0.05 hence there is no significant difference between Pakistani and Indonesian students' observational skills.

In drawing skills $\mathrm{P}$-value is 0.003 which is less than $0.05,0.003<0.05$ hence equal variance not assumed. While in the t-test for equality of variance $\mathrm{P}$-value is .377 which is bigger than $0.05,0.377>0.05$ hence there is no significant difference between Pakistani and Indonesian students drawing skills during performing chemistry practical. In reporting and interpretive skills sig value is 0.178 which indicates that the P-value is bigger than $0.05,0.178>$ 0.05 hence equal variance assumed. In t-test for quality of means $\mathrm{P}>0.05$ which is $.468>0.05$ which is a sign there is no significant difference between Pakistani and Indonesian students reporting and interpreting skills. Details are given in below table 5 . In some studies, Pakistani students score better than Indonesian students like in one of the studies the mean scores of Indonesian students were significantly lower than the mean scores of the Pakistani students which conclude that Indonesian students were more

Table 6. Independent samples test according to each aspect

\begin{tabular}{|c|c|c|c|c|c|c|}
\hline & & \multicolumn{2}{|c|}{$\begin{array}{l}\text { Levene's Test for Equality of } \\
\text { Variances }\end{array}$} & \multicolumn{2}{|c|}{ T-test for Equality of Means } & Conclusion \\
\hline Practicalskills & Variances & $\mathrm{F}$ & Sig. & $\mathrm{T}$ & Sig(2-tailed) & \\
\hline \multirow{2}{*}{$\begin{array}{l}\text { Experimental } \\
\text { and } \\
\text { Manipulative } \\
\text { skills }\end{array}$} & $1^{*[1]}$ & 5.392 & 0.022 & -24.285 & 0.000 & \multirow{2}{*}{$\begin{array}{l}\text { There is } \\
\text { significant } \\
\text { difference }\end{array}$} \\
\hline & $2^{*}[2]$ & & & -24.240 & 0.000 & \\
\hline \multirow{2}{*}{$\begin{array}{l}\text { Observational } \\
\text { skills }\end{array}$} & $1^{*}$ & 22.646 & 0.000 & -1.480 & 0.141 & \multirow{2}{*}{$\begin{array}{l}\text { There is no } \\
\text { significant } \\
\text { difference }\end{array}$} \\
\hline & $2^{*}$ & & & -1.485 & 0.140 & \\
\hline \multirow[t]{2}{*}{ Drawing skills } & $1^{*}$ & 9.173 & 0.003 & -0.885 & 0.378 & \multirow{2}{*}{$\begin{array}{l}\text { There is no } \\
\text { significant } \\
\text { difference }\end{array}$} \\
\hline & $2^{*}$ & & & -0.887 & 0.377 & \\
\hline \multirow{2}{*}{$\begin{array}{l}\text { Reporting and } \\
\text { Interpretive } \\
\text { skills }\end{array}$} & $1^{\star}$ & 1.833 & 0.178 & -0.727 & 0.468 & \multirow{2}{*}{$\begin{array}{l}\text { There is no } \\
\text { significant } \\
\text { difference }\end{array}$} \\
\hline & $2 *$ & & & -0.728 & 0.468 & \\
\hline
\end{tabular}

${ }^{1}$ Equal variance assumed

${ }^{2}$ Equal variance not assumed

\section{CONCLUSION}

The conclusion of this research shows that the overall view of practical skills between Pakistani and Indonesian undergraduate organic chemistry students in chemistry practical is significantly different Indonesian students show better skills during performing practical. The Four different aspects of different from Pakistani students in learning [16]. Some studies revealed that Indonesian students are more equipped with the latest tools of learning compared to Pakistani students. Indonesian students have good facilities in lab and instruments in the lab while Pakistani students on the other hand, not any such facility [19]. There are some studies that show no difference between two different types of genders as [2] explained that mostly there is no significant difference in comparison between male and female learning skills. In this research in most aspects, there is no significant difference except experimental and manipulatives skills. Subject-Based Teacher Groups Musyawarah Guru Mata Pelajaran (MGMP) a program in Indonesia which empowers programs and designed to make interested for teachers by engaging them in numerous activities such as microteaching activities, pedagogy workshops, action research and classroom observation and reflection [22]. Its proved if Pakistani teachers adopt microteaching, and continuous class observations it will help to improve the practical skills of organic chemistry undergraduate students. 
statistically no significant difference. Further research can show different results by using new aspects, which can show different and deep results.

\section{REFERENCES}

[1] I. Abrahams, M.J. Reiss, R.M. Sharpe, The Assessment of Practical Work in School Science, Studies in Science Education 49(2) (2013) 209251.

DOI: https://doi.org/10.1080/03057267.2013.858496

[2] N. Ahmed, N. Ahmed, A. Wiyarsi, R.N. Senam, Comparison of Students' Metacognitive Skills by Gender on Chemical Bonding in Chemistry, Jurnal Pendidikan Sains 7(2) (2019) 137. DOI: https://doi.org/10.26714/jps.7.2.2019.137-146

[3] T.A. Ali, Case Study of The Common Difficulties Experienced by High School Students in Chemistry Classroom in Gilgit-Baltistan (Pakistan), SAGE Open 2(2) 2012) 1-13.

[4] M. Aliakbari, K. Tazik, On The Relationship Between Gender and Perceptual Language Learning Styles: The Case of Iranian Academic EFL learners, Educational Psychology 31(6) (2011) 657-674. DOI: https://doi.org/10.1080/01443410.2011.592275

[5] A.S.S.A Sutiani, The Development of Innovative Learning Material with Problem Based Approach to Improve Students Competence in the Teaching of Physical Chemistry, in: $2^{\text {nd }}$ Annual International Seminar on Transformative Education and Educational Leadership, vol. 104, Atlantis Press, Amsterdam, 2017, pp. 378-382.

[6] Y.A.S. Anwar, S.W. Al Idrus, J. Siahaan, Implementasi Metode Presentasi pada Tahap Pra Laboratorium untuk Meningkatkan Kemampuan Menulis dan Sikap Mahasiswa Terhadap Kimia, Jurnal Inovasi Pendidikan IPA 5(2) (2019) 216228.

DOI: https://doi.org/10.21831/jipi.v5i2.24053

[7] K. Bayat, A. Rezaei, Importance of Teachers' Assessment Literacy, International Journal of English Language Education 3(1) 2014). DOI: https://doi.org/10.5296/ijele.v3i1.6887

[8] P.G. Brown, (2016). College Student Development in Digital Spaces, New Directions for Student Services 2016(155) 2016 59-73. DOI: https://doi.org/10.1002/ss.20183
[9] S.C. Elio, J.P. Herranz, G. Carro, A. Contreras, E.M. Camacho, F. Garcia-Loro, M.C. Gil, From a hands-on chemistry lab to a remote chemistry lab: Challenges and constrains, In Lecture Notes in Networks and Systems, Springer, Berlin, Heidberg 22 (2018) 125-131. DOI: https://doi.org/10.1007/978-3-319-64352-6_12

[10] S.O. Fakayode, Guided-Inquiry Laboratory Experiments In The Analytical Chemistry Laboratory Curriculum, Analytical and Bioanalytical Chemistry, Springer, Berlin, Heidberg 406(5) (2018) 1267-1271. DOI: https://doi.org/10.1007/s00216-013-7515-8

[11] I.B.A. Ghani, N.H. Ibrahim, N.A. Yahaya, J. Surif, Enhancing Students' HOTS In Laboratory Educational Activity By Using Concept Map As An Alternative Assessment Tool, Chemistry Education Research and Practice 18(4) (2017) 849-874.

DOI: https://doi.org/10.1039/c7rp00120g

12] N. Graulich, G. Bhattacharyya, Investigating Students' Similarity Judgments in Organic Chemistry, Chemistry Education Research and Practice 18(4) (2017) 774-784. DOI: https://doi.org/10.1039/c7rp00055c

[13] A. Hofstein, I. Dkeidek, D. Katchevitch, T.L. Nahum, M. Kipnis, O. Navon, R. Shore, D. Taitelbaum, R. Mamlok-Naaman, Research on and Development of Inquiry-Type Chemistry Laboratories in Israel, Israel Journal of Chemistry 59(6-7) (2019) 514-523. DOI: https://doi.org/10.1002/ijch.201800056

[14] A. Hofstein, V.N. Lunetta, The Laboratory in Science Education: Foundations for The TwentyFirst Century, Science Education 88 (2004) 2854. DOI: https://doi.org/10.1002/sce.10106

[15] H.M. Iqbal, M. Shayer, Accelerating The Development of Formal Thinking in Pakistan Secondary School Students: Achievement Effects and Professional Development Issues, Journal of Research in Science Teaching 37(3) (2000) 259-274. https://doi.org/10.1002/(SICI)10982736(200003 $\lcm{37: 3<259:: A I D-T E A 3>3.0 . C O ; 2-W}$

[16] M. Javed, L.S. Eng, A.R. Mohamed, R. Sam, Comparative Study of The Pakistani and Indonesian Student's Anxiety Towards The English Language Learning, Middle East Journal of Scientific Research 18(11) (2013) 1563-1572. DOI: 
https://doi.org/10.5829/idosi.mejsr.2013.18.11.1 $\underline{2456}$

[17] J.J. Lagowski, Analisis Kualitatif Semimikro, EGC, 2012.

[18] S. Moeed, Activity-based Learning and Development of High Mental Abilities an Intention of Intermediate Level Chemistry Syllabus, International Journal of Theory and Application in Elementary and Secondary School Education 1(2) (2019) 115-126 DOI: https://doi.org/10.31098/ijtaese.v1i2.37

[19] M.Q. Ali, A. Mahmood, D. Mutiara, Q. ul-Ain, Comparative Study of Pakistani and Indonesian Secondary Schools' ELT Resources and its Effective Utilization, Elixir International Journal Language and Testing (2016) 43530-43533.

[20] N. Reid, I. Shah, The Role of Laboratory Work in University Chemistry, Chemistry Education
Research and Practice 8(2) (2007) 172-185. DOI: https://doi.org/10.1039/B5RP90026C

[21] A. Sholahuddin, R. Yulinda, M.F. Sya'ban, R. Rasidah, Penguatan Kompetensi Guru dalam Optimalisasi Fungsi Laboratorium Bubungan Tinggi, Jurnal Pengabdian Masyarakat 1(1) (2019). DOI: https://doi.org/10.20527/btjpm.v1i1.1784

[22] T. Soebari, J.M. Aldridge, Investigating The Differential Effectiveness of A Teacher Professional Development Programme for Rural and Urban Classrooms in Indonesia, Teacher Development 20(5) (2016) 701-722. DOI: https://doi.org/10.1080/13664530.2016.1185031

[23] Z. Tatli, A, Ayas, Virtual Chemistry Laboratory: Effect of Constructivist Learning Environment, Turkish Online Journal of Distance Education 13(1) (2012) 183-199. 